\title{
Short-Term Ultraviolet (UV)-A Light-Emitting Diode (LED) Radiation Improves Biomass and Bioactive Compounds of Kale
}

\author{
Jin-Hui Lee ${ }^{1,2}$, Myung-Min $\mathrm{Oh}^{1,2 *}$ and Ki-Ho Son ${ }^{3}$ \\ ${ }^{1}$ Division of Animal, Horticultural and Food Science, Chungbuk National University, Cheongju, South Korea, ${ }^{2}$ Brain Korea \\ Center for Bio-Resource Development, Chungbuk National University, Cheongju, South Korea, ${ }^{3}$ Department of Horticultural \\ Science, College of Life Science, Gyeongnam National University of Science and Technology, Jinju, South Korea
}

OPEN ACCESS

Edited by:

Antonella Castagna,

University of Pisa, Italy

Reviewed by:

Sascha Rohn,

Universität Hamburg,

Germany

Branka Salopek Sondi,

Rudjer Boskovic Institute,

Croatia

${ }^{*}$ Correspondence:

Myung-Min Oh

moh@cbnu.ac.kr

Specialty section: This article was submitted to

Plant Abiotic Stress,

a section of the journal

Frontiers in Plant Science

Received: 05 April 2019

Accepted: 26 July 2019

Published: 20 August 2019

Citation:

Lee J-H, Oh M-M and Son K-H (2019) Short-Term Ultraviolet (UV)-A Light-Emitting Diode (LED) Radiation

Improves Biomass and Bioactive

Compounds of Kale.

Front. Plant Sci. 10:1042.

doi: 10.3389/fpls.2019.01042
The aim of this study was to determine the influence of two types of UV-A LEDs on the growth and accumulation of phytochemicals in kale (Brassica oleracea var. acephala). Fourteen-day-old kale seedlings were transferred to a growth chamber and cultivated for 3 weeks. The kale plants were subsequently subjected to two types of UV-A LEDs (370 and $385 \mathrm{~nm}$ ) of $30 \mathrm{~W} / \mathrm{m}^{2}$ for 5 days. Growth characteristics were all significantly increased in plants exposed to UV-A LEDs, especially at the $385 \mathrm{~nm}$ level, for which dry weight of shoots and roots were significantly increased by 2.22 and 2.5 times, respectively, at 5 days of treatment. Maximum quantum efficiency of photosystem II photochemistry (Fv/ Fm ratio) began to decrease after $3 \mathrm{~h}$ of treatment compared to the control. The total phenolic content of plants exposed to the two types of UV-A LEDs increased by $25 \%$ at $370 \mathrm{~nm}$ and $42 \%$ at $385 \mathrm{~nm}$ at 5 days of treatment, and antioxidant capacity also increased. The two types of UV-A LEDs also induced increasing contents of caffeic acid, ferulic acid, and kaempferol. The reactive oxygen species (ROS) temporarily increased in plants exposed to the two types of UV-A LEDs after $3 \mathrm{~h}$ of treatment. Moreover, transcript levels of phenylalanine ammonia-lyase (PAL), chalcone synthase (CHS), and flavanone 3-hydroxylase $(\mathrm{F} 3 \mathrm{H})$ genes and PAL enzyme activity were higher in plants treated with UV-A LEDs. Our results suggested that short-term UV-A LEDs were effective in increasing growth and improving antioxidant phenolic compounds in kale, thereby representing a potentially effective strategy for enhancing the production of phytochemicals.

Keywords: antioxidant capacity, kale, phenolic compound, reactive oxygen species, transcript level, UV-A LEDs

\section{INTRODUCTION}

Extreme environmental factors, such as temperature (low and high), water availability (deficit and flooding), light (ultraviolet and high light), salinity, and nutrient level (deficit and excess) that inhibit plant growth can be defined as abiotic stresses. Plants that are subjected to a high level or chronic abiotic stresses during growth and development experience cell damage as a result of oxidative stress induced by excessive production of radicals or non-radical reactive oxygen species (ROS), which eventually may lead to necrosis. However, plants subjected to endurable levels of abiotic stress or temporary abiotic stress often adapt to the stressful environment using inherent defense mechanisms (Drew, 1998); that 
is, many plants are capable of adapting to environmental conditions unsuitable for growth and development by activating various enzymatic or non-enzymatic antioxidant biosynthetic pathways as defense mechanisms, which reduce ROS levels resulting from external abiotic stress. Non-enzymatic antioxidants generated in plants act in a similar manner in the human body when humans ingest plant-based foodstuff, and thus, they reduce the risk of chronic and cardiovascular diseases and cancer, as well as slowing the effects of aging, by eliminating excessive ROS. Because of these beneficial effects, bioactive compounds, including antioxidants of plant-based food items, are increasingly attracting both scientific and public attention. Recently, the application of mild abiotic stress during plant cultivation has been recognized as a potential strategy for enhancing the production of bioactive compounds in vegetables (Akula and Ravishankar, 2011; Lee and Oh, 2015).

Ultraviolet light (200-400 nm), an abiotic stressor, comprises up to $7 \%$ of the total sunlight reaching the Earth (Müller-Xing et al., 2014). The UV light is divided into UV-C (200-280 $\mathrm{nm})$, UV-B (280-320 nm), and UV-A (320-400 nm) spectra, depending on wavelength. Irradiation with UV-C or UV-B, which are relatively high energy compared to UV-A, may cause fatal damage to plant biomolecules, proteins, and DNA, but UV-C is completely and UV-B mostly absorbed by the ozone layer of the atmosphere, with only a small amount of the latter (about 1.5\%) present in the sunlight reaching the Earth's surface. Approximately $98.7 \%$ of the UV radiation that reaches the Earth's surface is in the form of UV-A (Yarosh and Smiles, 2009), which therefore represents the primary type of natural irradiation available to plants.

The degree of plant response to UV light generally depends on the amount of energy (dosage) and the range of the spectrum, but even excessive UV-A (above ambient) levels can cause necrosis of plant cells or disruption of the photosynthesis apparatus, which is similar to the damage caused by UV-B exposure (Bidel et al., 2015). It was recently reported, however, that exposure to low-levels of UV-A radiation promotes the production of antioxidant compounds and photosynthetic pigments in plants, and stimulates overall plant growth (Tsormpatsidis et al., 2008; Brazaityte et al., 2010). Moreover, it was shown that supplemental UV-A light present in photosynthetically active radiation (PAR, 400-700 nm) enhanced chlorophyll and carotenoid concentrations, thereby promoting plant growth (Foyer et al., 1994; Ehling-Schultz et al., 1997). These results suggest that supplemental UV-A irradiation can improve the yield and/or quality of crops cultivated in greenhouses or otherwise grown under artificial light. However, the UV-A lamps most commonly used in previous research involving UV-A exposure encompass a wide range of UV-A wavelengths, including some visible light regions, making it difficult to identify the specific UV-A range or band responsible (Tsormpatsidis et al., 2008; Lee et al., 2014). Thus, a light source capable of intensive irradiation with a specific wavelength is required in order to explore the physiological responses of crop plants to the UV-A spectrum. Using UV-A LEDs that are energy efficient and have narrow peak wavelengths represent one potential approach, but little research has been carried out on the physiological responses of plants to such light sources.
We hypothesized that short-term UV-A radiation would increase the content of phenolic compounds without growth inhibition or with minimum inhibition. Our objective here was to determine the effects of irradiation with different types of UV-A LEDs on the growth and production of antioxidant phenolic compounds in kale, which are known to be rich in bioactive compounds, immediately before harvest, as a means of exploring the feasibility of using UV-A LED irradiation to improve kale quality without affecting plant growth or yield.

\section{MATERIAL AND METHODS}

\section{Plant Materials and Growth Conditions}

Kale seeds (Brassica oleracea var. acephala) were sown on seed growth packs (Seed Pack, Useem Instruments, Inc., Suwon, Korea) and germinated in an environmentally controlled closed plant production system [air temperature $20^{\circ} \mathrm{C}$; relative humidity $60 \%$; $\mathrm{CO}_{2} 400 \mu \mathrm{mol} \mathrm{mol}{ }^{-1}$; light period $12 \mathrm{~h}$; photosynthetic photon flux density (PPFD) $136 \pm 5 \mu \mathrm{mol} \mathrm{m}{ }^{-2} \mathrm{~s}^{-1}$ irradiated by fluorescent lamp] for 2 weeks. The 2 -week-old seedlings (total of 144 seedlings) were then transferred to a deep-flow technique (DFT) system and cultivated for a further 3 weeks. Half-strength Hoagland \& Arnon nutrient solution was used for mineral supply resources, and electrical conductivity (EC) and $\mathrm{pH}$ levels were corrected to $1.2 \mathrm{dS} \mathrm{m}^{-1}$ and 6.0 , respectively, with a digital multi-parameter (Multi 3430; WTW, Weilheim, Germany) once every 3 days.

\section{UV-A Treatments}

Two types of commercially available UV-A LEDs (370 and 385 nm, LG Innotek, Seoul, South Korea, Figure 1) were used as supplemental light sources to irradiate the kale cultivated in the DFT system continuously for 5 days. Light energy levels at the level of the plant canopy were set to $30 \mathrm{~W} / \mathrm{m}^{2}$ for both types of UV LEDs using Jaz spectrometer (Ocean Optics, Dunedin, FL, USA), whereas control plants were grown for 5 days under a normal existing fluorescent lamp.

\section{Biomass Characteristics}

In order to confirm the change of kale growth by UV-A LED treatment, kale biomass and leaf area were measured immediately before UV treatment and after 5 days of UV treatment. Fresh weights of shoots and roots were measured using an electronic scale (SI-234; Denver Instruments, Denver, CO, USA), and leaf area was measured using an area meter (LI-3100; LI-Cor, Lincoln, NE, USA). After measuring the fresh weight, shoots and roots were oven-dried separately (VS-1202D3; Vision Scientific, Daejeon, Korea) at $70^{\circ} \mathrm{C}$, following which dry weights of shoots and roots were determined.

\section{Photosynthetic Rate and Chlorophyll Fluorescence}

To assess changes in the photosynthetic rate of plants subjected to UV-A irradiation, $\mathrm{CO}_{2}$ concentrations in the fourth fully 


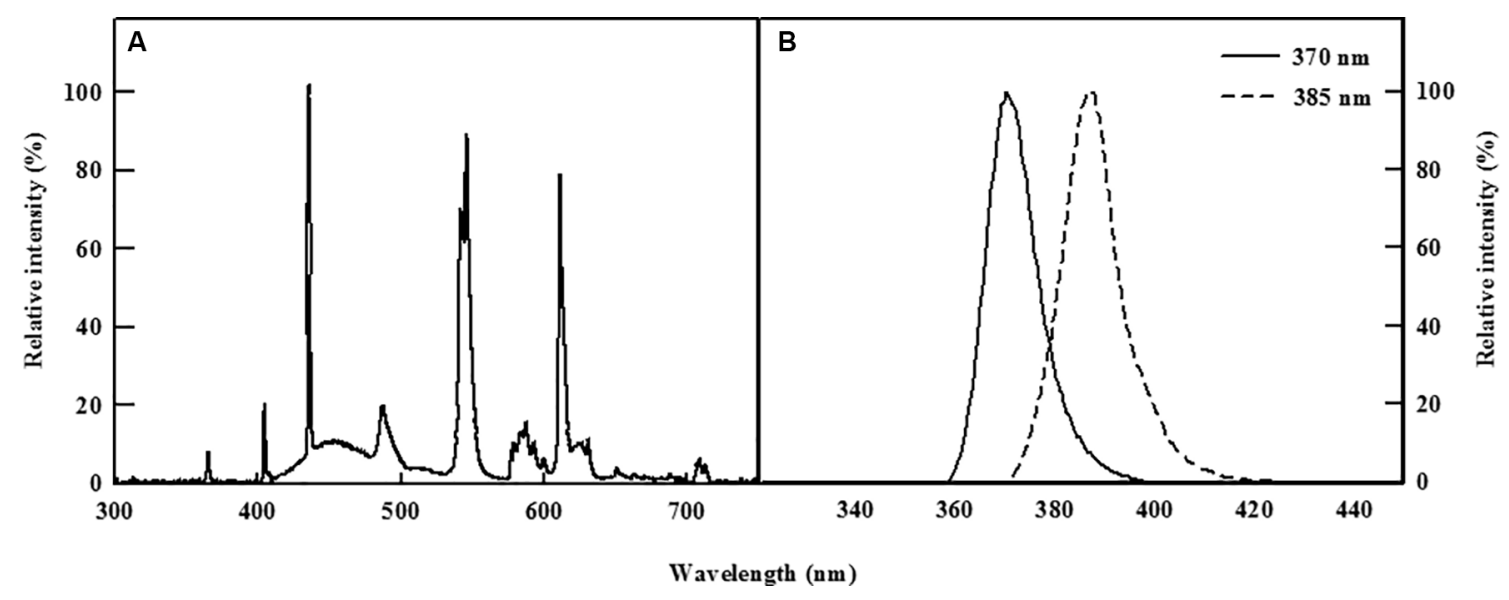

FIGURE 1 | Relative spectral distribution of the fluorescent lamp (A) and the two types of UV-A LEDs with 370 or 385 nm peak wavelength used (B).

expanded leaf were measured using a portable photosynthesis system (LI-6400; Li-Cor, Lincoln, NE, USA) at 4 days of UV-A LED treatment. Airflow rate, $\mathrm{CO}_{2}$ concentration, and the temperature inside the leaf cuvette were maintained at $350 \mu \mathrm{mol}$ $\mathrm{s}^{-1}, 400 \mu \mathrm{mol} \mathrm{mol}{ }^{-1}$, and $20^{\circ} \mathrm{C}$, respectively.

Maximum quantum efficiency of photosystem II photochemistry (Fv/Fm) was measured in the third leaf from the top of the shoot immediately before UV exposure and at first $3 \mathrm{~h}$ and then 12-h intervals during UV treatment using a chlorophyll fluorescence meter (PAM 2000; Heinz Walz GmbH, Effeltrich, Germany) to determine the stress level of plants receiving UV-A LED irradiation. Leaves were allowed to adjust to the dark for $30 \mathrm{~min}$ prior to the measurement, and maximum fluorescence (Fm) and minimum fluorescence (Fo) levels of the leaves were measured. Saturating light pulse and intensity was $20 \mathrm{kHz}$ and $1,100 \mu \mathrm{mol} \mathrm{m}{ }^{-2} \mathrm{~s}^{-1}$ PPFD, respectively. Ratios of Fv/Fm were calculated using the equation $\mathrm{Fv} / \mathrm{Fm}=(\mathrm{Fm}-\mathrm{Fo}) / \mathrm{Fm}$ (Maxwell and Johnson, 2000).

\section{Total Phenolic Content and Antioxidant Capacity}

Total phenolic content and antioxidant capacity were evaluated in order to examine how beneficial bioactive compounds were affected by UV-A irradiation immediately before treatment and at $3 \mathrm{~h}$ and $1,2,3,4$, and 5 days during UV treatment over the entire experimental period. The kale fresh leaf was used for the analysis. Approximately $200 \mathrm{mg}$ of fresh leaf sample was collected and stored in a deep freezer $\left(-70^{\circ} \mathrm{C}\right)$ until analysis. Total phenolic content was analyzed using the FolinCiocalteu method (Ainsworth and Gillespie, 2007), with minor modifications. Frozen samples were transferred to a mortar and then ground with liquid nitrogen. Acetone (80\%) was used for extraction, and the solution was incubated at $4^{\circ} \mathrm{C}$ for $12 \mathrm{~h}$. The extraction solution was centrifuged at $3,000 \times g$ for $2 \mathrm{~min}$, with the supernatant used in the analysis. The remaining analytical procedures followed those described by Lee and $\mathrm{Oh}$ (2015), and units were expressed as gallic acid equivalent (mg) per fresh weight (g) (GAE mg/g FW). Antioxidant capacity was determined via a slightly modified method using 2,2'-azino-bis (3-ethylbenzothiazoline-6-sulfonic acid) (ABTS; Sigma-Aldrich, St. Louis, MO, USA) (Miller and Rice-Evans, 1996). The samples were extracted in the same manner as those used in the analysis of total phenolic content and incubated at $-20^{\circ} \mathrm{C}$ for $12 \mathrm{~h}$, then centrifuged at $3,000 \times g$ for $2 \mathrm{~min}$, with the resulting supernatant used for the analysis. The remaining analytical procedures followed those described by Lee and Oh (2015). A standard curve was established using 6-hydroxy-2,5,7,8-tetramethylchroman-2carboxylic acid (Trolox; Sigma-Aldrich, St. Louis, MO, USA), and the units were expressed as Trolox-equivalent antioxidant capacity $(\mathrm{mM})$ per fresh weight (g) (TEAC mM/g FW).

\section{Individual Phenolic Compounds}

To analyze changes in the contents of individual phenolic compounds, kale leaf was collected immediately before and $3 \mathrm{~h}$ and $1,2,3,4$, and 5 days after initiation of UV-A exposure. The samples $(0.5 \mathrm{~g})$ were frozen in liquid nitrogen and stored at $-70^{\circ} \mathrm{C}$ until analysis, at which time they were ground in liquid nitrogen and extracted using acetonitrile and $0.5 \%$ hydrochloride acid solution. Extraction was performed as earlier described by Lin and Harnly (2009) with some modifications. The extracts of kale were subjected to acid hydrolysis to obtain the phenolic compounds aglycones for characterization. The extraction solution was acid-hydrolyzed for $2 \mathrm{~h}$ in a water bath at $85^{\circ} \mathrm{C}$, after which the solution was sonicated (Sk5210HP; Hangzhou Nade Scientific Instruments, Zhejiang, China) for $90 \mathrm{~min}$. Following centrifugation at $3,000 \times g$ for $20 \mathrm{~min}$, the supernatant was filtered through a syringe filter with a pore size of 0.22 $\mu \mathrm{m}$ (WKSPU0230; Woongki, Seoul, South Korea). Analysis of each of the phenolic compounds was performed with a highperformance liquid chromatography (HPLC) system (YL9100; Younglin, Anyang, Korea). An Agilent Eclipse Plus-C18 column

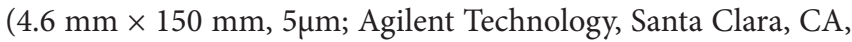
USA) equipped with a guard column was used. The column was operated at a temperature of $30^{\circ} \mathrm{C}$ and an injection volume of 10 $\mu$ l. The mobile phase consisted of $100 \%$ acetonitrile (eluent A) and $0.5 \%$ acetic acid in water (eluent $\mathrm{B}$ ). The gradient program 
consisted of $0-10 \mathrm{~min}: 10 \% \mathrm{~A} ; 10-30 \mathrm{~min}: 20 \% \mathrm{~A} ; 30-40 \mathrm{~min}$ : 30\% A; 40-50 min: 40\% A; 50-60 min: 80\% A; 60-61 min: 0\% A; and 61-70 min: $0 \% \mathrm{~A}$ (flow rate of $0.8 \mathrm{ml} \mathrm{min}^{-1}$ ). Absorbance was recorded at $320 \mathrm{~nm}$. Caffeic acid, ferulic acid, and kaempferol (Sigma-Aldrich, St. Louis, MO, USA) were used as standards. Contents of the individual phenolic compounds were expressed as mg per $100 \mathrm{~g}$ fresh weight (mg/100 $\mathrm{g} \mathrm{FW).}$

\section{Reactive Oxygen Species $\left(\mathrm{H}_{2} \mathrm{O}_{2}\right.$ and $\left.\mathrm{O}_{2}{ }^{--}\right)$}

Hydrogen peroxide $\left(\mathrm{H}_{2} \mathrm{O}_{2}\right)$ content was measured following the method described by Aroca et al. (2003). Approximately $0.5 \mathrm{~g}$ of fresh leaf tissue was collected (before and $3 \mathrm{~h}$ and 1, 2, 3,4 , and 5 days of UV-A treatment) and stored in a deep freezer (DF8524; IlShinBioBase, Dongducheon, Korea) at $-70^{\circ} \mathrm{C}$ until analysis. Kale samples were ground in a mortar with liquid nitrogen and homogenized with $5 \mathrm{ml}$ of $5 \%(\mathrm{w} / \mathrm{v})$ trichloroacetic acid (TCA) containing $0.1 \mathrm{~g}$ of activated charcoal and $1 \%(\mathrm{w} / \mathrm{v})$ polyvinylpolypyrrolidone (PVPP). The homogenized sample was centrifuged at $18,000 \times g$ for $10 \mathrm{~min}$, and the supernatant was filtered through a $0.22 \mu \mathrm{m}$ syringe filter. Following the addition of $1.2 \mathrm{ml}$ of $100 \mathrm{mM}$ potassium phosphate buffer $(\mathrm{pH}=8.4)$ and $0.6 \mathrm{ml}$ of colorimetric reagent to $130 \mu \mathrm{l}$ of the supernatant, the solution was incubated at $45^{\circ} \mathrm{C}$ for $1 \mathrm{~h}$ and absorbance was recorded at $508 \mathrm{~nm}$ using a spectrophotometer (UV-1800, Shimadzu, Kyoto, Japan). The colorimetric reagent was made by mixing $0.6 \mathrm{mM}$ potassium titanium oxalate and $0.6 \mathrm{mM} \mathrm{4-2}$ (2-pyridylazo) resorcinol (disodium salt) as 1:1 (v/v). Blanks were constructed with 5\% TCA instead of the extracted solution, and units were expressed as $\mathrm{H}_{2} \mathrm{O}_{2}(\mathrm{nmol})$ per fresh weight $(\mathrm{g})$ (nmol g-1 FW).

Superoxide radical $\left(\mathrm{O}_{2}{ }^{-}\right)$content was measured following the method described by Wang and Luo (1990). Approximately $0.5 \mathrm{~g}$ of frozen sample was made into powder by grinding with liquid nitrogen and subsequently mixed with $5 \mathrm{ml}$ of $50 \mathrm{mM}$ potassium phosphate buffer $(\mathrm{pH}=7.8)$. After centrifuging at $5,000 \times g$ for $15 \mathrm{~min}, 1 \mathrm{ml}$ of the supernatant was mixed with $0.9 \mathrm{ml}$ of $50 \mathrm{mM}$ potassium phosphate buffer $(\mathrm{pH}=7.8)$ and $0.1 \mathrm{ml}$ of $10 \mathrm{mM}$ hydroxylamine hydrochloride. The mixed solution was incubated at $25^{\circ} \mathrm{C}$ for $30 \mathrm{~min}$, and subsequently, 1 $\mathrm{ml}$ of $17 \mathrm{mM} 3$-aminobenzenesulfonic acid and $1 \mathrm{ml}$ of $7 \mathrm{mM}$ 1 -naphthylamine were added to $1 \mathrm{ml}$ of the incubated solution. The solution was once again incubated at $25^{\circ} \mathrm{C}$ for an additional $20 \mathrm{~min}$, following which absorbance was measured at $530 \mathrm{~nm}$. Units were expressed as mmol of $\mathrm{O}_{2}{ }^{--}$per hour per gram of fresh weight $\left(\mathrm{mmol} \mathrm{O}_{2}{ }^{--} \mathrm{h}^{-1} \mathrm{~g}^{-1} \mathrm{FW}\right)$.

\section{Phenylalanine Ammonia-Lyase (PAL) Enzyme Activity}

Phenylalanine ammonia-lyase (PAL) activity was analyzed following the method of Boo et al. (2011), with minor modification. The fresh leaf segment $(\sim 0.5 \mathrm{~g})$ was used for the analysis. Samples were collected immediately prior to UV exposure and at first $3 \mathrm{~h}$ and then 1-day intervals over the course of 5 days of UV-A treatment and stored in a deep freezer (DF8524; IlShinBioBase, Dongducheon, Korea) at $-70^{\circ} \mathrm{C}$ until analysis. We used the method described by Lee and Oh (2015) for the analysis. The standard curve was constructed by transcinnamic acid (Sigma-Aldrich, St. Louis, MO, USA). Units were expressed as $\mathrm{mM}$ of trans-cinnamic acid per hour per gram of fresh weight ( $\mathrm{mM}$ trans-cinnamic acid $\mathrm{h}^{-1} \mathrm{~g}^{-1} \mathrm{FW}$ ).

\section{Transcriptional Levels of PAL, CHS, and F3H Genes}

To compare the transcriptional levels of the PAL, chalcone synthase (CHS), and flavanone 3-hydroxylase (F3H) genes, which are essential for biosynthesis of phenolic compounds in kale leaves, leaf segment was collected $(\sim 0.2 \mathrm{~g})$ (before and $3 \mathrm{~h}$ and $1,2,3,4$, and 5 days of UV-A treatment) and stored at $-70^{\circ} \mathrm{C}$ in a deep freezer until analysis. Total RNA was extracted using an RNeasy Plant Mini Kit (74904; QIAGEN, Hilden, Germany), and the concentration was checked with a NanoDrop 1000 Spectrophotometer (Thermo Scientific, Wilmington, USA), whereas cDNA synthesis was performed with a QuantiTect Reverse Transcription Kit (QIAGEN, Hilden, Germany). Quantitative real-time PCR was performed using a $2 \times$ QuantiMix SYBR Kit (PhileKorea, Daejeon, Korea) for the PAL gene, and a $2 \times$ MakTaq ReMix (T121M, QIAGEN, Hilden, Germany) for the CHS and F3H genes. Products of PAL, CHS, and F3H were amplified with a Rotor-gene 6000 (Corbett Life Science, Sydney, Australia). The oligonucleotide primers used in the experiments were constructed based on information obtained from the GenBank database (Table 1). The PCR conditions for the PAL gene were as follows: $95^{\circ} \mathrm{C}$ for $5 \mathrm{~min}$ for the pre-denaturing stage and in the subsequent 33 cycles, consisting of denaturing $\left(95^{\circ} \mathrm{C}\right.$ for $\left.30 \mathrm{~s}\right)$, annealing $\left(60^{\circ} \mathrm{C}\right.$ for $\left.120 \mathrm{~s}\right)$, and extension $\left(72^{\circ} \mathrm{C}\right.$ for $90 \mathrm{~s}$ ). The PCR conditions for the $\mathrm{CHS}$ and $\mathrm{F} 3 \mathrm{H}$ genes were as follows: $95^{\circ} \mathrm{C}$ for $2 \mathrm{~min}$ for the pre-denaturing stage and in the subsequent 40 cycles, consisting of denaturing $\left(95^{\circ} \mathrm{C}\right.$ for 5 $\mathrm{s})$, annealing $\left(60^{\circ} \mathrm{C}\right.$ for $\left.20 \mathrm{~s}\right)$, and extension $\left(72^{\circ} \mathrm{C}\right.$ for $\left.20 \mathrm{~s}\right)$. The degree of relative gene expression $(\triangle \Delta \mathrm{CT})$ was calculated using Rotor-gene 1.7 software (QIAGEN, Hilden, Germany).

TABLE 1 | List of oligonucleotide primers used for quantitative-real-time PCR.

\begin{tabular}{|c|c|c|c|}
\hline Gene name ${ }^{z}$ & Forward primer sequence & Reverse primer sequence & PCR product (bp) \\
\hline BoActin & GAACTACGAGTTGCCCGACG & GCAGCTTCCATTCCCACGAA & $20 / 20$ \\
\hline BoPAL & CTCGACCCTTGGAAACGGTG & CCGTTCTTGGTTCTCCGGTG & $20 / 20$ \\
\hline $\mathrm{BoCHS}$ & СССТСТGАСАСССАССТTGA & GCGGCAGACACCATCTCAAA & $20 / 20$ \\
\hline $\mathrm{BoF} 3 \mathrm{H}$ & CGGCGTGGATGTGAAAGGAA & CAGCTTCTCCGGCGTAACTC & $20 / 20$ \\
\hline
\end{tabular}

"GenBank accession numbers for Actin, PAL, CHS, and F3H are KF218591.1, FJ849059.1, EF531094.1, and EF531096.1, respectively. 


\section{Statistical Analysis}

Statistical analyses were performed with SAS (SAS 9.2; SAS Institute, Cary, NC, USA). Each parameter included four biological replicates except for photosynthetic rate and Fv/Fm, which had five biological replicates and subjected to analysis of variance (ANOVA). The experiment was repeated twice to confirm reproducibility. Tukey's range test (HSD) was used to compare the means between treatments, with statistical significance expressed at $p<0.05$.

\section{RESULTS}

\section{Growth Characteristics}

Fresh and dry weights of shoots and roots, leaf area, and specific leaf weight were significantly higher in kale irradiated with the two types of UV-A LEDs for 5 days (Table 2). Shoot fresh weight exposed to $370 \mathrm{~nm}$ and $385 \mathrm{~nm}$ wavelengths increased by 1.32 and 1.58 times, and shoot dry weight by 1.57 and 1.95 times, respectively, compared to control plants. In addition, fresh and dry weights of roots increased in plants subjected to both UV-A treatments and significantly increased (by 2.22 and 2.5 times) in plants exposed to $385 \mathrm{~nm}$ wavelengths compared to control plants, respectively. In addition, leaf area in plants treated with UV-A LEDs at wavelengths of $385 \mathrm{~nm}$ was 1.42 times higher than the leaf area of control plants, and specific leaf weight (an indication of leaf thickness) was also significantly higher, by 1.15 and 1.43 times, in plants exposed to UV-A wavelengths of 370 and $385 \mathrm{~nm}$, respectively, compared to controls.

\section{Photosynthetic Rate and Chlorophyll Fluorescence}

Photosynthetic rates of kale leaves irradiated by UV-A LEDs for 4 days are shown in Figure 2A. The highest photosynthetic rate was observed in the control plants, followed by plants exposed to UV-A at wavelengths of 385 and $370 \mathrm{~nm}$, respectively, but none of these differences were statistically significant. However, significant differences

TABLE 2 | Growth characteristics of kale immediately prior to UV treatment and 5 days of UV treatments $(n=4)$.

\begin{tabular}{|c|c|c|c|c|c|c|c|}
\hline \multirow[t]{2}{*}{ Time } & \multirow[t]{2}{*}{ Treatment } & \multicolumn{2}{|c|}{ Shoot } & \multicolumn{2}{|c|}{ Root } & \multirow[t]{2}{*}{ Leaf area $\left(\mathrm{cm}^{2}\right)$} & \multirow{2}{*}{$\begin{array}{c}\text { Specific } \\
\text { leaf weight } \\
\left(\mathrm{mg} \mathrm{cm} \mathbf{c m}^{-2}\right)\end{array}$} \\
\hline & & Fresh weight (g) & Dry weight (g) & Fresh weight (g) & Dry weight (g) & & \\
\hline Before treatment $Z$ & & $4.18 \pm 0.20^{y}$ & $0.31 \pm 0.01$ & $0.52 \pm 0.05$ & $0.03 \pm 0.01$ & $107.02 \pm 5.31$ & 0.0029 \\
\hline \multirow[t]{4}{*}{5 days of treatment } & Control & $7.19 \pm 0.36 b^{x}$ & $0.52 \pm 0.03 b$ & $0.70 \pm 0.07 b$ & $0.05 \pm 0.01 c$ & $179.34 \pm 6.74 b$ & $0.0029 b$ \\
\hline & $370 \mathrm{~nm}$ & $9.49 \pm 0.56 a b$ & $0.83 \pm 0.04 a$ & $1.09 \pm 0.06 b$ & $0.09 \pm 0.01 b$ & $207.52 \pm 11.38 b$ & $0.0040 a$ \\
\hline & $385 \mathrm{~nm}$ & $11.39 \pm 0.90 a$ & $1.03 \pm 0.09 a$ & $1.57 \pm 0.17 a$ & $0.12 \pm 0.01 \mathrm{a}$ & $255.97 \pm 14.25 a$ & $0.0040 a$ \\
\hline & Significance & $\star \star$ & $\star \star \star$ & $\star \star$ & $\star \star \star ~$ & $\star \star \star$ & $\star \star$ \\
\hline
\end{tabular}

zUV non-treated plant

'Data are presented as mean \pm SE.

“Mean separation within columns by Tukey's range test (HSD).

**, ***ignificant at $p<0.01$ and $p<0.001$, respectively.

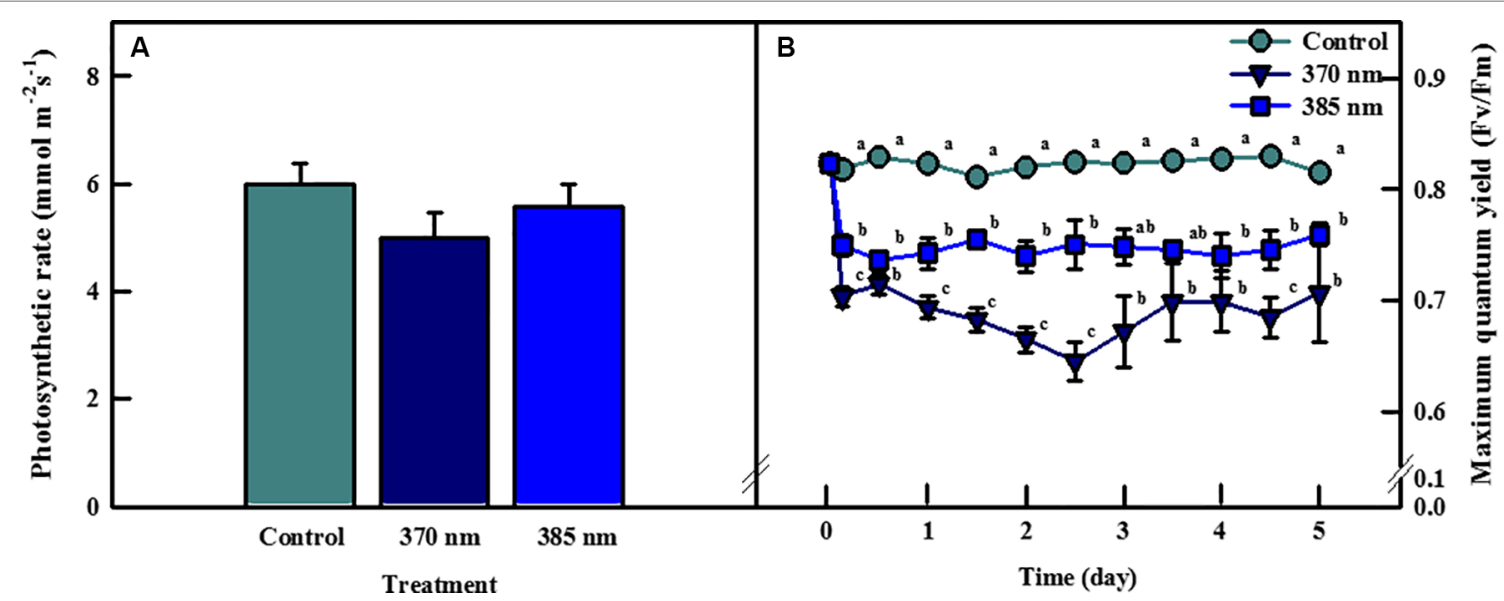

FIGURE 2 | Photosynthetic rate of kale subjected to two types of UV-LED lights (370 and 385 nm) at 4 days (A) and maximum quantum efficiency of photosystem ॥ (Fv/Fm) of kale subjected to two types of UV-LED lights ( 370 and $385 \mathrm{~nm}$ ) for 5 days (B). The vertical bars indicate standard errors ( $\mathrm{n}=5)$. Different letters indicate significant differences, as assessed by ANOVA $(\rho<0.05)$. 
were detected between control plants and those exposed to the two types of UV-A LEDs in terms of maximum quantum efficiency of photosystem II photochemistry (Fv/Fm), a non-destructive stress indicator (Figure 2B). The Fv/Fm ratio rapidly decreased over the initial $3 \mathrm{~h}$ of UV-A LED irradiation (by 0.70 at $370 \mathrm{~nm}$ and 0.75 at 385 $\mathrm{nm}$ ) and remained below 0.8 over the entire period of UV-A LED exposure. The Fv/Fm ratio in plants exposed to the 385 $\mathrm{nm}$ wavelength ranged from 0.73 to 0.76 , whereas in plants exposed to the $370 \mathrm{~nm}$ treatment the $\mathrm{Fv} / \mathrm{Fm}$ ratio was $0.04-0.1$ lower than the $385 \mathrm{~nm}$ plants at 1-4 days of UV-A irradiation.

\section{Total Phenolic Content and Antioxidant Capacity}

Total phenolic content and antioxidant capacity of kale leaves differed according to time, and the peak wavelength of UV-A LED irradiation (Figure 3). Total phenolic content in plants exposed to UV-A $370 \mathrm{~nm}$ significantly increased, by $14 \%$, compared to the control following $3 \mathrm{~h}$ of UV-A irradiation, then decreased over the next 2 days of treatments, but significantly increased thereafter, by $15 \%$ and $26 \%$ after 4 and 5 days of treatment, respectively. Total phenolic content also increased in plants treated with UV-A $385 \mathrm{~nm}$ for the first $1-3$ days, and significantly so by days 4 and 5 , by $44 \%$ and $42 \%$ compared to control plants, respectively. Antioxidant capacity exhibited a similar trend: at 4 and 5 days of UV-A LEDs treatment, plants exposed to UV-A $370 \mathrm{~nm}$ experienced a significant increase in antioxidant capacity of $15 \%$ and $29 \%$, respectively, and that of plants exposed to UV-A $385 \mathrm{~nm}$ by $45 \%$ and $51 \%$, respectively, compared to control plants.

\section{Individual Phenolic Compounds}

Irradiation with UV-A LEDs was effective in enhancing the contents of the phenolic compounds caffeic acid, ferulic acid, and kaempferol (Figure 4). Caffeic acid contents were 2 and
1.82 times higher in plants exposed to UV-A $370 \mathrm{~nm}$ and UV-A $385 \mathrm{~nm}$, respectively, than in control plants within $3 \mathrm{~h}$ of treatment, and remained significantly higher thereafter. Most notably, plants treated with UV-A $385 \mathrm{~nm}$ had 4.86 and 4.55 times more caffeic acid than control plants after 3 and 5 days of treatment, respectively. Ferulic acid contents were also higher in plants exposed to the two UV-A LEDs treatments, but these differences were not statistically significant. Finally, kaempferol contents exhibited a pattern similar to that of caffeic acid; UV-A $385 \mathrm{~nm}$ plants had 3.18 times as much kaempferol as did control plants after 2 days of treatment, a statistically significant difference, whereas kaempferol contents were 1.46 and 1.68 times higher in plants treated with UV-A $370 \mathrm{~nm}$ and UV-A $385 \mathrm{~nm}$ compared to control plants after 5 days of treatment, respectively, which were also statistically significant.

\section{Reactive Oxygen Species $\left(\mathrm{H}_{2} \mathrm{O}_{2}\right.$ and $\left.\mathrm{O}_{2}{ }^{-*}\right)$}

The dynamics of ROS contents in plants under UV-A irradiation differed from that in control plants (Figure 5). Hydrogen peroxide contents were $8 \%$ higher in the $370 \mathrm{~nm}$ treated plants than in control plants at $3 \mathrm{~h}$ of UV-A treatment, after which they decreased continuously until 2 days of treatment, at which point $\mathrm{H}_{2} \mathrm{O}_{2}$ contents were $8 \%$ lower than in the controls. Hydrogen peroxide content then recovered to levels similar to control plants after 3 days of treatment, but then declined once more at 5 days of treatment. For plants exposed to UV-A $385 \mathrm{~nm}$, $\mathrm{H}_{2} \mathrm{O}_{2}$ levels were slightly lower than in control plants after $3 \mathrm{~h}$ of treatment and 19\% lower by 2 days of treatment. At 5 days of treatment, however, $\mathrm{H}_{2} \mathrm{O}_{2}$ contents were more or less the same in both treated and control plants.

Superoxide contents increased by $5 \%$ at $3 \mathrm{~h}$ but then decreased by $7 \%$ after 1 day of treatment in UV-A $370 \mathrm{~nm}$ plants compared to controls, although contents remained higher in the treated plants after 3 days of treatment. For kale receiving UV-A $385 \mathrm{~nm}$, superoxide content increased to the

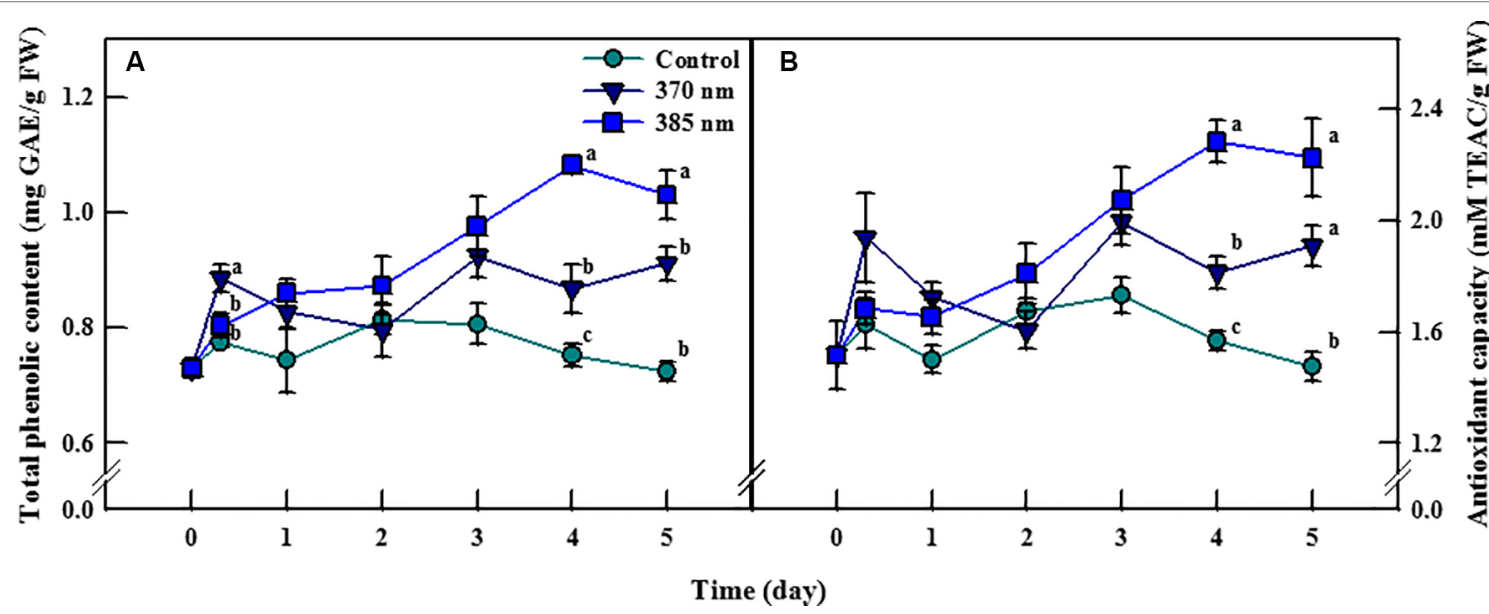

FIGURE 3 | Total phenolic content (A) and antioxidant capacity (B) of kale subjected to two types of UV-A LED lights for 5 days. The vertical bars indicate standard errors $(n=4)$. Different letters indicate significant differences, as assessed by ANOVA $(p<0.05)$. 


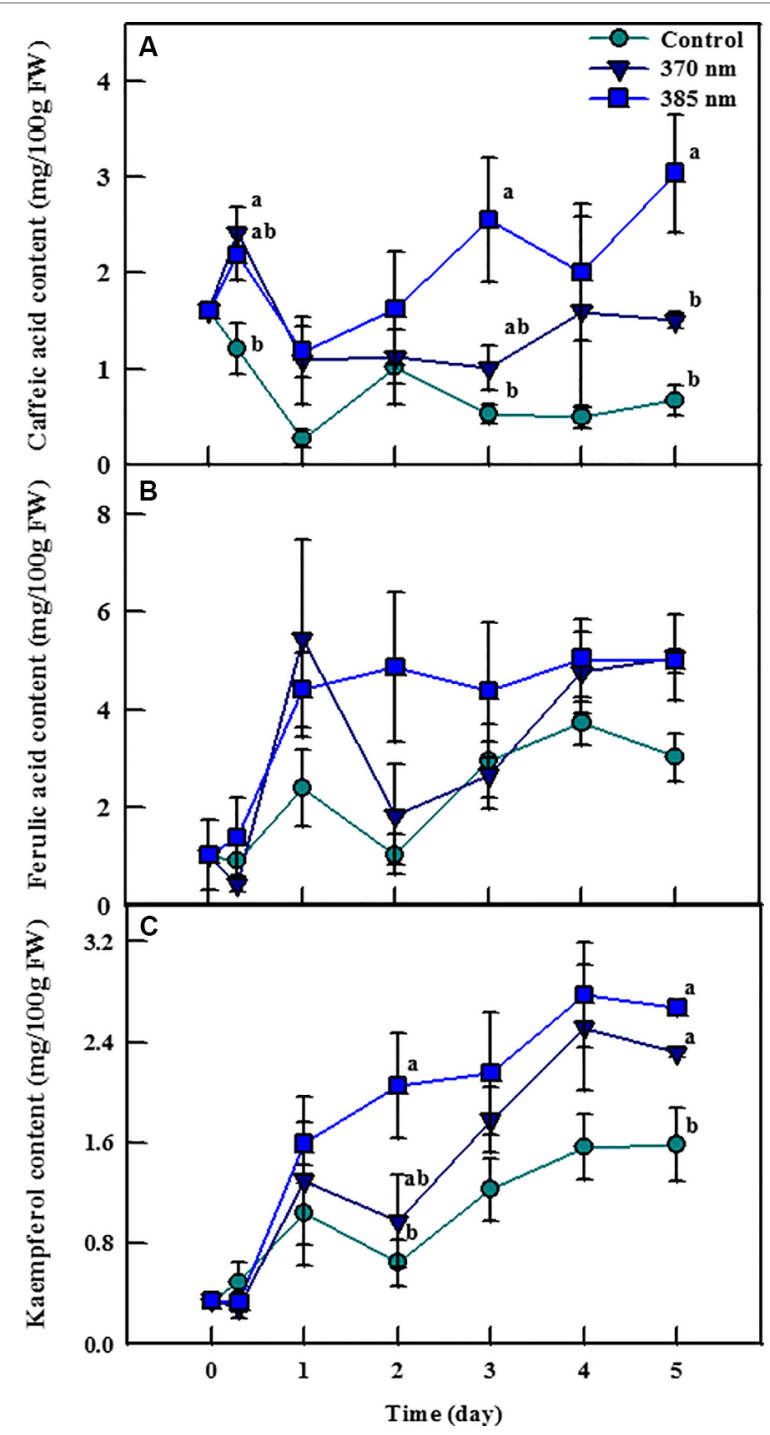

FIGURE 4 | Individual phenolic compounds [caffeic acid; (A) ferulic acid; (B) and kaempferol; (C)] of kale subjected to two types of UV-A LED lights for 5 days. The vertical bars indicate standard errors $(n=4)$. Different letters indicate significant differences, as assessed by ANOVA $(p<0.05)$.

same level as that for plants treated with UV-A $370 \mathrm{~nm}$ at $3 \mathrm{~h}$ but fell to control levels at 1 day of treatment. In this case, however, superoxide contents began to increase after 4 days of treatment and were approximately $5 \%$ higher than in control plants by 5 days.

\section{PAL Enzyme Activity}

The activity of the PAL enzyme-a gateway enzyme in the biosynthesis pathway of secondary metabolites (phenolic compounds) - was significantly higher in plants treated with UV-A $385 \mathrm{~nm}$ at 1 day of treatment, with activity levels $44 \%$ higher than in the control plants (Figure 6A). PAL enzyme activity slightly decreased until 3 days of treatment in UV-A irradiated kale, but remained significantly higher, by $11 \%$ and $7 \%$, than in control plants at 4 and 5 days of treatment, respectively. For plants receiving UV-A $370 \mathrm{~nm}$, PAL activity increased at 1 day of treatment, but thereafter, there no significant differences in PAL activity were detected between the treated plants and the controls.

\section{Transcript Levels of the PAL, CHS, and F3H Genes}

Transcript levels of the PAL, CHS, and $\mathrm{F} 3 \mathrm{H}$ genes changed considerably with the time of exposure to UV-A irradiation (Figures 6B-D). Transcript levels of the PAL gene were lower at both 370 and $385 \mathrm{~nm}$ treated plants than in controls at $3 \mathrm{~h}$ of treatment, but then increased beginning 1 day after the initiation of the treatments. In plants treated with UV-A 370 $\mathrm{nm}, \mathrm{PAL}$ transcript levels were higher than in plants treated with UV-A $385 \mathrm{~nm}$ but increased more rapidly in the UV-A $385 \mathrm{~nm}$ plants than in the UV-A $370 \mathrm{~nm}$ plants after 1 day of treatment. Transcription of the PAL gene increased by 1.8 and 2.3 times in the UV-A 370 and UV-A 385 plants compared to controls at 3 days of treatment (Figure 6B). Transcript levels of the CHS gene also drastically increased in both UV-A 370 and UV-A $385 \mathrm{~nm}$ plants at 1 day of treatment, by 3.2 and 2 times compared to the controls, respectively. However, the CHS gene was deactivated in plants of both treatments after 2 days, then reactivated at 3 days; overall, $\mathrm{CHS}$ gene transcription was higher in plants exposed to UV-A $385 \mathrm{~nm}$ (3.4 times compared to controls) than in plants exposed to UV-A $370 \mathrm{~nm}$ (2.1 times), a pattern similar to that for the PAL gene (Figure 6C). Finally, although transcript levels of the $\mathrm{F} 3 \mathrm{H}$ gene were higher in UV-A treated kale than in control plants at 1,3 , and 5 days of treatment, these differences were not statistically significant (Figure 6D).

\section{DISCUSSION}

\section{Biomass}

UV-A light effect on plant growth and development is known to be regulated by several factors such as environmental condition, dose of UV energy, plant species, and genotype (Cooley et al., 2001). However, exposure to UV light is generally believed to have deleterious effects on plant growth; for example, UV-A irradiation of $69.33 \mu \mathrm{mol} \mathrm{m} \mathrm{m}^{-2} \mathrm{~s}^{-1}$ and UV-B of $5.10 \mu \mathrm{mol} \mathrm{m}{ }^{-2} \mathrm{~s}^{-1}$ were shown to inhibit the growth of Amaranthus tricolor (Kataria et al., 2013), and three cultivars of Triticum sativum subjected to UV-A of $63.5 \mathrm{~W} / \mathrm{m}^{2}$ and UV-B of $2.7 \mathrm{~W} / \mathrm{m}^{2}$ also exhibited slower growth rates (Häder, 1996). In our study, however, short-term exposure to two types of UV-A LEDs with $370 \mathrm{~nm}$ or $385 \mathrm{~nm}$ peak wavelength induced significant increases in several growth parameters of kale, a result consistent with those reported by Brazaityte et al. (2015), in which growth-related parameters such as plant height, leaf area, and fresh weight were enhanced in basil, beet, 


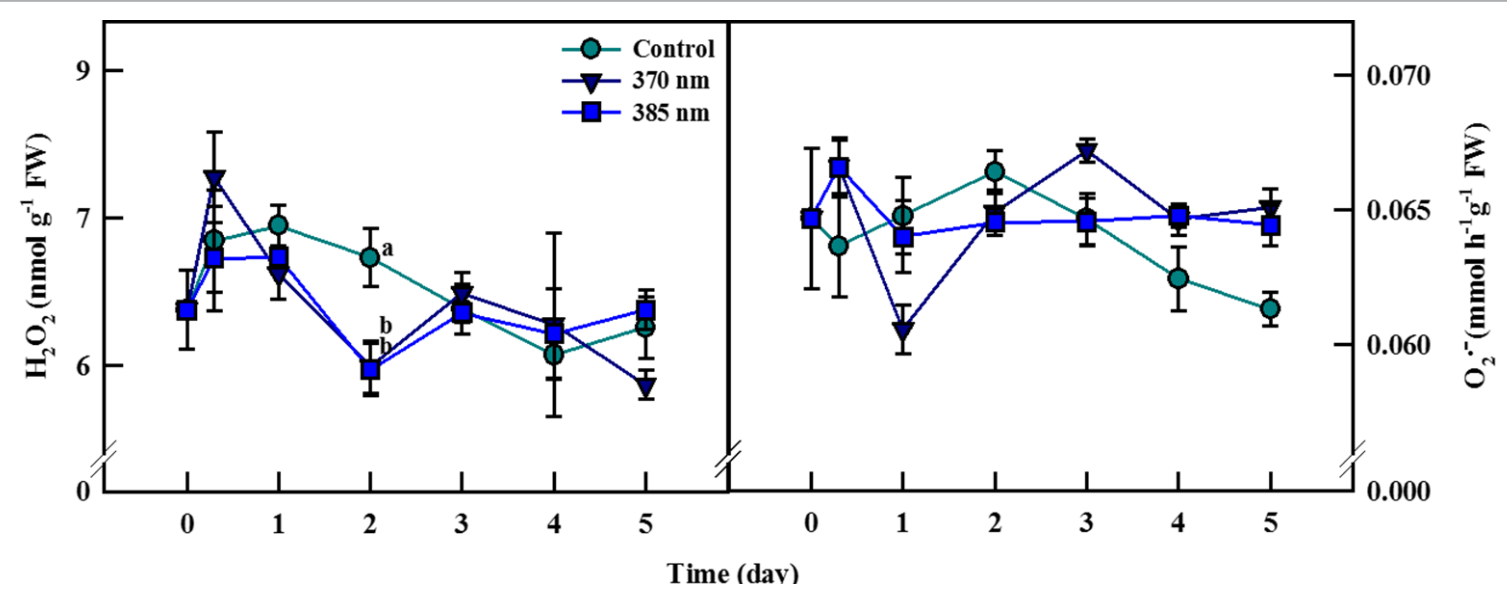

FIGURE 5 | Hydrogen peroxide (A) and superoxide radical (B) of kale subjected to two types of UV-A LED lights for 5 days. The vertical bars indicate standard errors $(n=4)$. Different letters indicate significant differences, as assessed by ANOVA $(p<0.05)$.
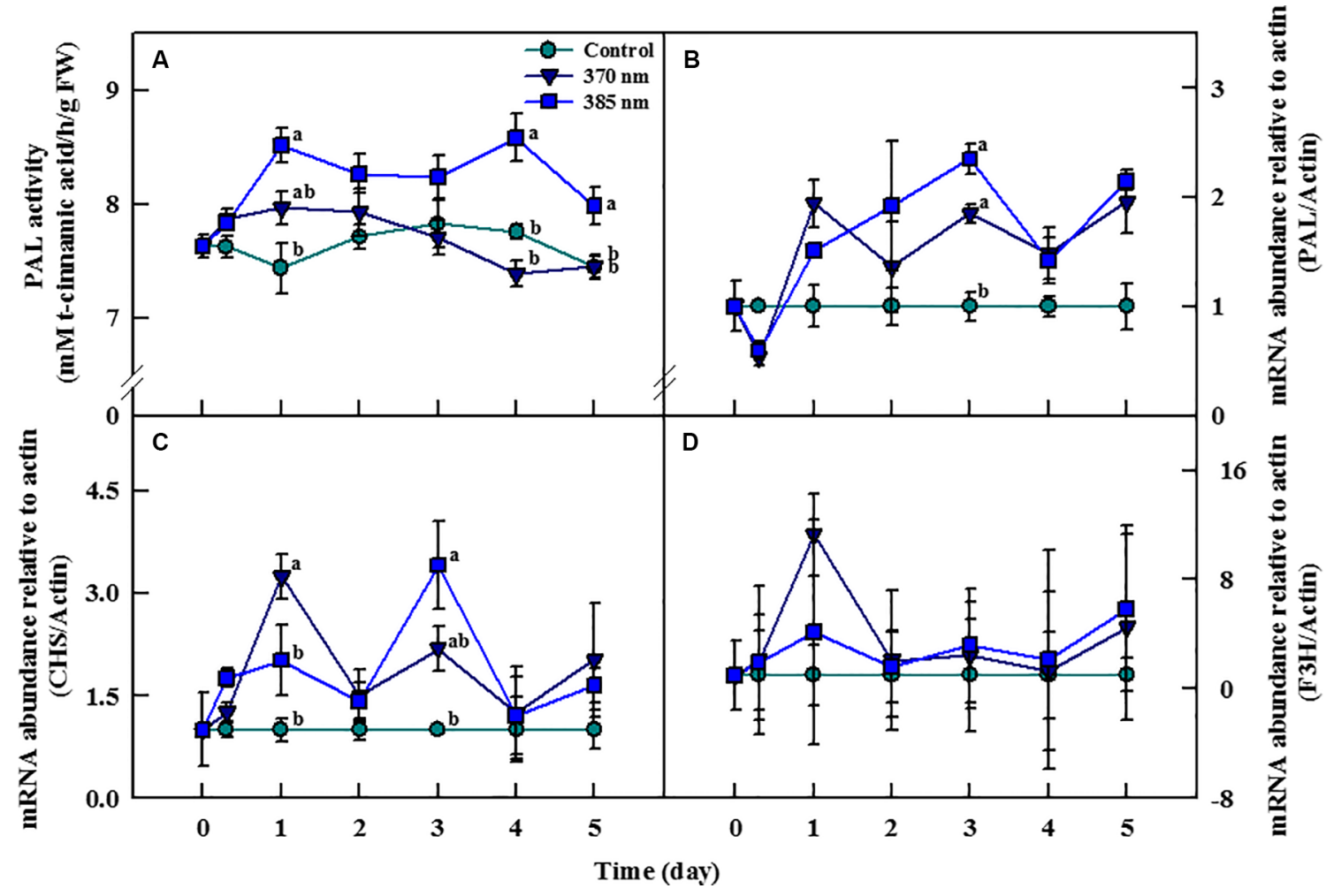

FIGURE 6 | Phenylalanine ammonia-lyase (PAL) activity (A) and transcript levels of PAL (B), chalcone synthase (CHS) (C), and flavonoid 3-hydroxylase (F3H) genes (D) of kale subjected to two types of UV-A LED lights for 5 days. Gene expression levels were normalized to that of actin gene, a housekeeping gene. The vertical bars indicate standard errors $(n=4)$. Different letters indicate significant differences, as assessed by ANOVA $(p<0.05)$.

and pak choi microgreens following exposure to UV-A LEDs with peak wavelengths of 390 and $402 \mathrm{~nm}$. In addition, lettuce growth improved when plants were irradiated with UV-A in the bandwidth of $370-400 \mathrm{~nm}$ and the remaining UV-A range and UV-B were excluded via UV film under sunlight (Tsormpatsidis et al., 2008). These results suggest that some
UV-A LED wavelengths are used in photosynthesis in addition to the visible light regions (> $400 \mathrm{~nm}$ ) (Figure 1), and/or that UV-A wavelengths close to $400 \mathrm{~nm}$ might also be light sources available for photosynthesis. This is supported here by the comparative superiority of UV-A LED $385 \mathrm{~nm}$ than $370 \mathrm{~nm}$ in inducing positive responses in growth parameters in kale 
(Table 1). Additional evidence can be seen in the results of Brazaityte et al. (2015), in which basil and pak choi subjected to several types of UV-A LEDs of $6.2 \mu \mathrm{mol} \mathrm{m} \mathrm{m}^{-2} \mathrm{~s}^{-1}$ (peak wavelengths: 366,390 , and $402 \mathrm{~nm}$ ) exhibited improved plant height, hypocotyl length, fresh weight, and chlorophyll index at longer peak wavelengths. Verdaguer et al. (2017) noted that direct absorption of UV-A light energy by chlorophyll and carotenoids enhanced photosynthetic activity when UV-A was supplemented under low PAR conditions, implying that UV-A LED irradiation could be used as an additional source of light energy available for use in photosynthesis when light intensities fail to reach the light saturation point. Blue-green fluorescence excited from UV-A light absorbed by secondary metabolites such as phenolic compounds in leaf cells can be used indirectly as photosynthetic energy (Mantha et al., 2001; Johnson and Day, 2002). In our study, irradiation with UV-A was at a lower intensity $\left(136 \mu \mathrm{mol} \mathrm{m} \mathrm{m}^{-2} \mathrm{~s}^{-1}\right.$ of PPFD) than the light saturation point $\left(>400 \mu \mathrm{mol} \mathrm{m} \mathrm{m}^{-2} \mathrm{~s}^{-1}\right.$ ) of kale, yet the photosynthetic rates of plants exposed to UV-A 370 $\mathrm{nm}$ and UV-A $385 \mathrm{~nm}$ were slightly lower than that of control plants at 4 days of treatment, although these differences were not statistically significant (Figure 2A). The inconsistency of the results for the growth and photosynthetic rates can be explained by the fact that in our experiment plants were continuously irradiated with UV-A LED for 5 days regardless of the period of visible light, and therefore, plants receiving UV-A were exposed to higher levels of the daily light integral (DLI) required for growth promotion than were control plants, which may have contributed to the improvements observed in their growth-related parameters (Torres and Lopez, 2011). In addition, increases in stomatal conductance, leaf soluble proteins, and nitrogen uptake by UV-A light may be another reason of positive effect on the photosynthesis (Tezuka et al., 1994; Mantha et al., 2001). Moreover, photoreceptors related to UV-A light are involved in long-distance signal transmission to regulate root growth (Zhang et al., 2014), resulting in the accumulation of root biomass as well as shoot biomass.

\section{Chlorophyll Fluorescence}

Most of the light energy absorbed by chlorophylls is used for photosynthesis, and the rest is re-irradiated in the form of heat and fluorescence. Minimum fluorescence (Fo) indicates the smallest amount of fluorescence generated by chlorophyll molecules in the PS II antenna before the light energy moves to the PS II reaction center, whereas and maximum fluorescence (Fm) indicates the largest amount of fluorescence emission of a dark-adapted plant exposed to a short pulse of a strong light, leading to a transient reduction of quinone acceptor. Thus, the Fv/Fm $(=\mathrm{Fm}-\mathrm{Fo}) / \mathrm{Fm})$ ratio quantifies the response of the plant to external environmental stress by measuring the maximum quantum efficiency of PS II (Parkhill et al., 2001). The Fv/Fm ratio (as an indirect indicator of stress) typically ranges between 0.81 and 0.83 in healthy plants but falls below this level in plants subjected to stress conditions, because Fo increases and Fm decreases (Song and Hansen, 1994). In our study, the Fv/Fm ratio was within the normal range, averaging
0.82 , in the control plants, but averaged 0.7 and 0.75 in plants in the UV-A $370 \mathrm{~nm}$ and UV-A $385 \mathrm{~nm}$ treatments, respectively, thus lower than the normal range, indicating that the plants were stressed by UV-A LED irradiation. In previous studies, UV-A radiation affected directly decrease in the efficiency of the electron transport system of chloroplasts in wheat seedlings and spinach plants (Joshi et al., 1994; Turcsányi and Vass, 2000). The lower Fv/Fm ratio in the UV-A $370 \mathrm{~nm}$ plants suggested that even though the amount of energy irradiated $\left(=30 \mathrm{~W} / \mathrm{m}^{2}\right)$ was the same, UV-A at wavelengths of $370 \mathrm{~nm}$, which is a shorter wavelength and contains one quantum more energy than wavelengths of $385 \mathrm{~nm}$, was a stronger plant stressor than was UV-A at $385 \mathrm{~nm}$. This implies that the consideration of peak wavelength of UV-A LEDs is required for the use in horticultural areas such as vertical farms or greenhouses.

\section{Bioactive Compounds}

In general, UV irradiation with strong energy potential may damage not only DNA and proteins but also photosynthetic apparatus, thereby adversely affecting plant growth (Diffey, 1991). However, irradiation using UV with relatively weak energy, such as UV-A, induces a variety of protective response mechanisms in plants and accumulation of low-molecular compounds like antioxidants that act to inhibit oxidative damage (Bharti and Khurana, 1997). Here, we found that kale subjected to two UV-A LEDs (370 and $385 \mathrm{~nm}$ ) with 30 $\mathrm{W} / \mathrm{m}^{2}$ for 5 days did not exhibit any morphological damage, suggesting that these UV wavelengths were not strong enough to cause permanent oxidative damage. At the same time, the increases in total phenolic content and antioxidant capacity in plants under these levels of UV-A irradiation (Figure 3) indicated that the irradiation treatment was within an appropriate range to stimulate biosynthesis of antioxidant phenolic compounds in kale. At $3 \mathrm{~h}$ of UV treatment, the significant increase in total phenolic content and antioxidant capacity in plants subjected to UV-A $370 \mathrm{~nm}$, which has higher energy per photon than does UV-A $385 \mathrm{~nm}$, suggested that UV-A $370 \mathrm{~nm}$ was a more effective stimulator despite both having the same energy level $\left(30 \mathrm{~W} / \mathrm{m}^{2}\right)$. However, as UV treatment continued through 4-5 days, the UV-A $385 \mathrm{~nm}$ treatment induced a gradual increase in the production of bioactive compounds (total phenolic content and antioxidant capacity, expressed in mg) per unit fresh weight. This is a very intriguing result, in that it is not a concentrated effect given that the UV-A $385 \mathrm{~nm}$ treatment did not inhibit but rather increased kale fresh weight. In other words, irradiation with UV-A $385 \mathrm{~nm}$ was beneficial to both plant growth and the production of bioactive compounds. A similar trend was observed in microgreens of basil, beet, and pak choi subjected to UV-A LED light (Brazaitytè et al., 2015). This can be explained by the allocation of additional carbohydrates, which resulted from the enhanced photosynthesis triggered by exposure to UV-A irradiation, toward the production of both biomass and secondary metabolites (Ghasemzadeh et al., 2010). In addition, the activation of cryptochromes 
(Cry), which are photoreceptors for blue and UV-A lights, by UV-A radiation may stimulate the accumulation of phenolic compounds (Brelsford et al., 2019). However, further studies are needed to understand the interactions between photoreceptors and UV-A radiation in terms of biosynthetic pathways of secondary metabolites (Verdaguer et al., 2017).

Typically two classes of phenolic compounds (hydroxycinnamic acids and flavonoids) are involved in epidermal UV screening in plants (Berli et al., 2010). Our results also showed that these UV-absorbing compounds were found in kale leaves. The phenolic compounds convert shortwavelength with high-energy and destructive radiation into longer wavelength, which is less destructive to the cellular structures of a leaf, including the photosynthetic apparatus such as thylakoids (Bilger et al., 2001). Indeed, flavonoids and hydroxycinnamic acids are known to provide better UV-A waveband protection because absorption maxima of flavonoids and hydroxycinnamic acid were 350-390 and 310$332 \mathrm{~nm}$, respectively (Cerovic et al., 2002; Tattini et al., 2004). The contents of caffeic acid and kaempferol were higher in plants treated with UV-A LEDs at 5 days of treatment, which was a consistent result of total phenolic content and antioxidant capacity. The UV-A LED $385 \mathrm{~nm}$ treatment was more effective in enhancing caffeic acid content than was the UV-A $370 \mathrm{~nm}$ treatment, indicating that the energy level of UV-A LED $385 \mathrm{~nm}$ was more appropriate for increasing production of the individual phenolic compounds, as was observed for total phenol content and antioxidant capacity. However, Moreira-Rodríguez et al. (2017) reported that contents of gallic acid hexoside I (GAH I), gallic acid hexoside II (GAH II), gallotannic acid (GTA), p-hydroxybenzoic acid (p-HBA), and gallic acid derivative (GAD), which are also phenolic compounds, were higher in broccoli sprouts exposed to elevated UV-A levels $\left(4.05 \mathrm{~W} / \mathrm{m}^{2}\right)$ compared to plants exposed to lower UV-A levels, indicating that the energy level of UV-A is a critical factor for stimulating the increased production of individual phenolic compounds in broccoli sprouts. These contrasting results of the optimum energy level of UV-A imply that even if different plant species are treated with the same UV-A dosage, they may respond in different ways, as for each there is a unique optimal level of UV intensity. Differential response of phenolic compounds according to the level of UV-A and -B radiation was also reported by Heinze et al. (2018). In the study, various kaempferol glycosides and hydroxycinnamic acid derivatives increased in pak choi plants irradiated with UV-B $\left(0.0049 \mathrm{~W} / \mathrm{m}^{2}\right)$ and UV-A (50 $\mathrm{W} / \mathrm{m}^{2}$ ) compared to plants exposed to low UV conditions (UV-B: $0.0006 \mathrm{~W} / \mathrm{m}^{2}$, UV-A: $1 \mathrm{~W} / \mathrm{m}^{2}$ ). Meanwhile, Neugart et al. (2012) suggested that temporary radiation of UV-B affects the accumulation of phenolic compounds such as flavonol glycosides and hydroxycinnamic acid derivatives in kale plants but the pattern was complicated and there was an effect of structure-dependent reaction on the biosynthesis of these phenolic compounds. Given all, each group of phenolic compounds may change depending on the UV energy-dose, chemical structure, and individual plant species (Olsson et al., 1998; Reifenrath and Müller, 2007; Neugart et al., 2012).
Irradiation with UV is known to activate the expression of several genes encoding important enzymes, including PAL, $\mathrm{CHS}$, and $\mathrm{F} 3 \mathrm{H}$, in the phenylpropanoid pathway (Fuglevand et al., 1996). PAL and CHS are key enzymes that catalyze the initial stages of phenylpropanoid and flavonoid biosynthesis, respectively, and $\mathrm{F} 3 \mathrm{H}$ is an essential enzyme in the flavonoid biosynthetic pathway, as it catalyzes the 3-hydroxylation of (2S)-flavanones, such as the conversion of naringenin to dihydroflavonols (Wanner et al., 1995; Liu et al., 2013). The activities of these enzymes ultimately lead to the production of UV-absorbing phenolic compounds and thus mitigation of plant-tissue damage caused by exposure to UV light (Middleton and Teramura, 1993). Our results also demonstrated that short-term irradiation with UV-A LEDs activated the transcript level of the PAL, CHS, and F3H genes in kale leaves and increased PAL enzyme activity. PAL gene expression significantly increased in plants exposed to both UV-A 370 $\mathrm{nm}$ and UV-A $385 \mathrm{~nm}$ after 3 days of treatment and continued to increase after 4 and 5 days. Our results corroborated those found previously for lettuce and tomato, in which PAL gene expression and PAL enzyme activity increased in lettuce and tomato plants exposed to UV-A irradiation for 7 days and 24 h, respectively (Guo and Wang, 2010; Lee et al., 2014). The transcript level of the CHS gene significantly increased after 3 days of treatment, similar to that of the PAL gene, whereas the transcript level of the $\mathrm{F} 3 \mathrm{H}$ gene increased but not to statistically significant levels. Likewise, previous research has shown that exposure to UV-A and UV-B activates the CHS and $\mathrm{F} 3 \mathrm{H}$ genes in turnip and lettuce, respectively (Zhou et al., 2007; Liu et al., 2013). In addition, low level of UV-A light activated the transcript level of UVR8 gene, which is generally activated by UV-B radiation and promotes the production of antioxidants (Brelsford et al., 2019). In the study, Arabidopsis accumulates flavonoids by stimulating in response to low UV-A dose (peak emission; $365 \mathrm{~nm}, 15 \mu \mathrm{mol} \mathrm{m} \mathrm{m}^{-2} \mathrm{~s}^{-1}$ ). The response of genes related to secondary metabolite productions to UV-A irradiation is further evidence that the results of the significantly increased total phenol content and antioxidant capacity after 4 and 5 days of UV-A treatment were due to activation of the biosynthetic pathways responsible for the production of secondary metabolites. It has been reported that UV treatment increases flavonoid concentration (Reifenrath and Müller, 2007), UV-absorbing pigments, flavonols, and total antioxidant activity (Csepregi et al., 2017) in leaves of all ages (within a single plant), although there is a difference in the degree of increased. Therefore, the difference in the degree of bioactive compounds increased by UV-A LED treatment is also considered to be negligible, because samples of each parameter were collected from leaves of the same age.

\section{Reactive Oxygen Species $\left(\mathrm{H}_{2} \mathrm{O}_{2}\right.$ and $\left.\mathrm{O}_{2}{ }^{-}\right)$}

Reactive oxygen species are reactive chemicals with unpaired electrons in the outer orbit and are composed of free radicals and non-free radicals such as hydrogen peroxide $\left(\mathrm{H}_{2} \mathrm{O}_{2}\right)$, superoxide $\left(\mathrm{O}_{2}{ }^{--}\right)$, singlet oxygen $\left({ }^{1} \mathrm{O}_{2}\right)$, and hydroxyl radical $(\cdot \mathrm{OH})$ (Riley, 1994). ROS generally occur when energy is 
generated from nutrients and oxygen under normal conditions (Poljsak et al., 2013), and levels of ROS normally rise when a plant is exposed to environmental stress, including exposure to UV light (Couée et al., 2006; Heinze et al., 2018). In our study, contents of $\mathrm{O}_{2}{ }^{--}$and $\mathrm{H}_{2} \mathrm{O}_{2}$ increased in plants treated with UV-A $370 \mathrm{~nm}$ compared to control plants at $3 \mathrm{~h}$ of treatment, indicating that ROS was rapidly generated in response to UV-A stimulation (Figure 5). This rapid increase of ROS, called reactive oxygen burst, is the earliest responses of plant cells under various abiotic stress and regulates signaling network that controls responses downstream (Bhattacharjee, 2005). Razem and Bernards (2003) also reported that initial ROS burst occurred within $1 \mathrm{~h}$ of exposure to abiotic stresses such as wounding in carrot plants. Moreover, we observed dynamic changes in ROS levels in the controls as well as in plants in both UV treatments, but UV treatment appeared to alter the pattern of change in ROS levels observed in the control plants. Changes in $\mathrm{O}_{2}{ }^{--}$followed a similar pattern to that of $\mathrm{H}_{2} \mathrm{O}_{2}$, albeit with a $\sim 1$-day delay, which can be explained by the fact that superoxide anion radicals are converted into $\mathrm{H}_{2} \mathrm{O}_{2}$ spontaneously or by superoxide dismutase (SOD) in the reaction pathway (Kyaw et al., 2004).

Manipulation of ROS levels in plants is associated with a positive feedback loop between ROS perception and ROS production (Mittler et al., 2004). In plants, oxidative damage by ROS produced under normal conditions is usually mitigated by enzymatic and non-enzymatic antioxidants, thus ensuring that normal cellular redox homeostasis between the ROS and the antioxidants is maintained, and ROS levels are subsequently kept within a certain range. However, excess ROS are often produced when plants are subjected to environmental stress, which acts as an oxidative stress signal to stimulate the activation of stress-response mechanisms, including antioxidant production (Dixon and Paiva, 1995; Chen et al., 2008; Miller et al., 2010). Jacobo-Velázquez et al. (2011) reported that wounding and hypoxia stresses elevated the level of ROS in carrot plants, which activated the transcript level of PAL resulting in enhancement of total phenolic content. Our results also demonstrated the correlation between ROS generated by UV-A exposure and antioxidant response: because the UV-A $370 \mathrm{~nm}$ treatment involved higher energy levels than the UV-A $385 \mathrm{~nm}$ treatment, ROS levels rapidly increased after $3 \mathrm{~h}$ in plants treated with UV-A $370 \mathrm{~nm}$, following which antioxidant activity also sharply increased in response to the higher contents of ROS. After that point, antioxidant levels began to fall until they reached levels similar to those observed in control plants after 2 days of treatment (Figure 3B). The no accumulation of antioxidants in kale irradiated by UV-A LEDs at the initial treatment stage may be explained by excessive ROS production compared to antioxidants that quench ROS. A similar trend was observed in tobacco leaves subjected to UV-B light (Shen et al., 2017). However, antioxidant capacity then increased once more after 3 days of treatment, despite ROS levels staying more or less the same. This may be because the initial 2 days of treatment was a period of adjustment for plants exposed to UV irradiation, and UV-A $370 \mathrm{~nm}$ irradiation acted as a mild stress that led to a slight increase in antioxidant phenolics production after 3 days of treatment. In contrast, ROS production was not excessive in plants exposed to UV-A $385 \mathrm{~nm}$ because the energy level at this wavelength is considerably lower than at the UV-A $370 \mathrm{~nm}$ wavelength, but exposure to UV-A 385 $\mathrm{nm}$ may still be sufficient to induce antioxidant synthesis as a stimulatory signal given that antioxidative phenolics production was more efficient in kale plants exposed to UV-A 385 than exposed to UV-A $370 \mathrm{~nm}$. This point was very interesting, but we need further study to clearly elucidate the effect of UV-A wavelength on growth and the accumulation of secondary metabolites in plants.

\section{CONCLUSION}

Short-term irradiation using UV-A LEDs of different peak wavelengths (370 and $385 \mathrm{~nm}$ ) improved several growth parameters and enhanced the production of antioxidant phenolic compounds in kale, with effects more pronounced in plants exposed to UV-A $385 \mathrm{~nm}$, which is closer to the visible light range than is UV-A $370 \mathrm{~nm}$. Treatment with UV-A LEDs increased ROS levels in the plant, which stimulated the production of secondary metabolites through overexpression of several key genes (PAL, CHS, and $\mathrm{F} 3 \mathrm{H}$ ) important to the biosynthetic pathways of these compounds and activation of the PAL enzyme. Thus, contents of total phenolic and individual phenolic compounds, as well as antioxidant capacity, increased in response to UV-A LED irradiation. Our results suggested that short-term exposure to UV-A LED irradiation represents an effective means of stimulating the production of certain secondary metabolites, including phenolic compounds, in kale. However, given that excessive levels of UV irradiation cause damage to plants, additional research focusing on developmental stage, energy dose, and various UV-A peak wavelength is needed to establish the specific optimal standards for crop species and varieties.

\section{DATA AVAILABILITY}

The datasets generated for this study can be found in GenBank, KF218591.1, FJ849059.1, EF531094.1, and EF531096.1.

\section{AUTHOR CONTRIBUTIONS}

J-HL carried out the measurements and data analysis and drafted the manuscript. K-HS participated in the part of measurements and gene expression analysis. M-MO made a substantial guide about experimental design and critically revised the manuscript.

\section{FUNDING}

This study was supported by the fund of National Research Foundation of Korea (NRF-2014R1A1A1007793). 


\section{REFERENCES}

Ainsworth, E. A., and Gillespie, G. M. (2007). Estimation of total phenolic content and other oxidation substrates in plant tissues using Folin-Ciocalteu reagent. Nat. Protoc. 2, 875-877. doi: 10.1038/nprot.2007.102

Akula, R., and Ravishankar, G. A. (2011). Influence of abiotic stress signals on secondary metabolites in plants. Plant Signal. Behav. 6, 1720-1731. doi: 10.4161/psb.6.11.17613

Aroca, R., Irigoyen, J. J., and Sánchez-Díaz, M. (2003). Drought enhances maize chilling tolerance. II. Photosynthetic traits and protective mechanisms against oxidative stress. Plant Sci 117, 540-549. doi: 10.1034/j.1399-3054.2003.00065.x

Bharti, A. K., and Khurana, J. P. (1997). Mutants of arabidopsis as tools to understand the regulation of phenylpropanoid pathway and UVB protection mechanisms. Photochem. Photobiol. 655, 765-776. doi: 10.1111/j.17511097.1997.tb01923.x

Berli, F. J., Moreno, D., Piccoli, P., Hespanhol-Viana, L., Silva, M. F., Bressan-Smith, R., et al. (2010). Abscisic acid is involved in the response of grape (Vitis vinifera L.) $\mathrm{cv}$. Malbec leaf tissues to ultraviolet-B radiation by enhancing ultravioletabsorbing compounds, antioxidant enzymes and membrane sterols. Plant Cell Environ. 33, 1-10. doi: 10.1111/j.1365-3040.2009.02044.x

Bhattacharjee, S. (2005). Reactive oxygen species and oxidative burst: roles in stress, senescence and signal transducation in plants. Curr. Sci. 89, 1113-1121.

Bidel, L. P., Chomicki, G., Bonini, F., Mondolot, L., Soulé, J., Coumans, M., et al. (2015). Dynamics of flavonol accumulation in leaf tissues under different UV-B regimes in Centella asiatica (Apiaceae). Planta 2423, 545-559. doi: 10.1007/ s00425-015-2291-7

Bilger, W., Johnsen, T., and Schreiber, U. (2001). UV-excited chlorophyll fluorescence as a tool for the assessment of UV-protection by the epidermis of plants. J. Exp. Bot. 52, 2007-2014. doi: 10.1093/jexbot/52.363.2007

Boo, H. O., Heo, B. G., Gorinstein, S., and Chon, S. U. (2011). Positive effects of temperature and growth conditions on enzymatic and antioxidant status in lettuce plants. Plant Sci. 181, 479-484. doi: 10.1016/j.plantsci. 2011.07.013

Brazaitytė, A., Duchovskis, P., Urbonavičiūtė, A., Samuolienė, G., Jankauskienè, J., Sakalauskaite, J., et al. (2010). The effect of light-emitting diodes lighting on the growth of tomato transplants. Zemdirbyste 97, 89-98.

Brazaitytè, A., Viršilè, A., Jankauskienè, J., Sakalauskienė, S., Samuolienė, G., Sirtautas, R., et al. (2015). Effect of supplemental UV-A irradiation in solidstate lighting on the growth and phytochemical content of microgreens. Int. Agrophys 291, 13-22. doi: 10.1515/intag-2015-0004

Brelsford, C. C., Morales, L. O., Nezval, J., Kotilainen, T. K., Hartikainen, S. M., Aphalo, P. J., et al. (2019). Do UV-A radiation and blue light during growth prime leaves to cope with acute high light in photoreceptor mutants of Arabidopsis thaliana? Physiol. Plant. 165, 537-554. doi: 10.1111/ppl.12749

Cerovic, Z. G., Ounis, A., Cartelat, A., Latouche, G., Goulas, Y., Meyer, S., et al. (2002). The use of chlorophyll fluorescence excitation spectra for the nondestructive in situ assessment of UV-absorbing compounds in leaves. Plant Cell Environ. 25, 1663-1676. doi: 10.1046/j.1365-3040.2002.00942.x

Chen, J. Y., He, L. H., Jiang, Y. M., Wang, Y., Joyce, D. C., Ji, Z. L., et al. (2008). Role of phenylalanine ammonia-lyase in heat pretreatment-induced chilling tolerance in banana fruit. Physiol. Plant. 132, 318-328. doi: 10.1111/j.1399-3054.2007.01013.x

Cooley, N. M., Higgins, J. T., Holmes, M. G., and Attridge, T. H. (2001). Ecotypic differences in responses of Arabidopsis thaliana L. @ to elevated polychromatic UV-A and UV-B + A radiation in the natural environment: a positive correlation between UV-B + A inhibition and growth rate. J. Photochem. Photobiol. B, Biol. 60, 143-150. doi: 10.1016/S1011-1344(01)00140-3

Couée, I., Sulmon, C., Gouesbet, G., and Amrani, A. E. (2006). Involvement of soluble sugars in reactive oxygen species balance and responses to oxidative stress in plants. J. Exp. Bot. 573, 449-459. doi: 10.1093/jxb/erj027

Csepregi, K., Coffey, A., Cunningham, N., Prinsen, E., Hideg, É., and Jansen, M. A. (2017). Developmental age and UV-B exposure co-determine antioxidant capacity and flavonol accumulation in arabidopsis leaves. Environ. Exp. Bot. 140, 19-25. doi: 10.1016/j.envexpbot.2017.05.009

Diffey, B. L. (1991). Solar ultraviolet radiation effects on biological systems. Phys. Med. Biol. 363, 299. doi: 10.1088/0031-9155/36/3/001

Dixon, R. A., and Paiva, N. L. (1995). Stress-induced phenylpropanoid metabolism. Plant Cell 7, 1085-1097. doi: 10.2307/3870059
Drew, M. (1998). "Stress physiology”, in Plant Physiol. Eds. L. Taiz and E. Zeiger (Sunderland, MA: Sinauer Associates), 725-757.

Ehling-Schultz, M., Bilger, W., and Scherer, S. (1997). UV-B induced synthesis of photoprotective pigments and extracellular polysaccharides in the terrestrial cyanobacterium Nostoc commune. J. Bacteriol. 179, 1940-1945. doi: 10.1128/ jb.179.6.1940-1945.1997

Foyer, C. H., Lelandais, M., and Kunert, K. J. (1994). Photooxidative stress in plants. Physiol. Plant. 924, 696-717. doi: 10.1111/j.1399-3054.1994.tb03042.x

Fuglevand, G., Jackson, J. A., and Jenkins, G. I. (1996). UV-B, UV-A and blue light signal transduction pathways interact synergistically to regulate chalcone synthase gene expression in arabidopsis. Plant Cell 8, 2347-2357. doi: 10.1105/ tpc.8.12.2347

Ghasemzadeh, A., Jaafar, H. Z., and Rahmat, A. (2010). Elevated carbon dioxide increases contents of flavonoids and phenolic compounds, and antioxidant activities in Malaysian young ginger (Zingiber officinale Roscoe.) varieties. Molecules 1511, 7907-7922. doi: 10.3390/molecules15117907

Guo, J., and Wang, M. H. (2010). Ultraviolet A-specific induction of anthocyanin biosynthesis and PAL expression in tomato (Solanum lycopersicum L.). Plant Growth Regul. 621, 1-8. doi: 10.1007/s10725-010-9472-y

Häder, D. P. (1996). Effects of solar radiation on local and German wheat seedlings in a Chilean high mountain station. J. Photochem. Photobiol. B, Biol. 35, 181187. doi: 10.1016/S1011-1344(96)07296-X

Heinze, M., Hanschen, F. S., Wiesner-Reinhold, M., Baldermann, S., Gräfe, J., Schreiner, M., et al. (2018). Effects of developmental stages and reduced UVB and low UV conditions on plant secondary metabolite profiles in pak choi (Brassica rapa subsp. chinensis). J. Agric. Food Chem. 66, 1678-1692. doi: 10.1021/acs.jafc.7b03996

Jacobo-Velázquez, D. A., Martínez-Hernández, G. B., Del, C., Rodríguez, S., Cao, C. M., and Cisneros-Zevallos, L. (2011). Plants as biofactories: physiological role of reactive oxygen species on the accumulation of phenolic antioxidants in carrot tissue under wounding and hyperoxia stress. J. Agric. Food Chem. 59, 6583-6593. doi: 10.1021/jf2006529

Johnson, G. A., and Day, T. A. (2002). Enhancement of photosynthesis in Sorghum bicolor by ultraviolet radiation. Physiol. Plant. 116, 554-562. doi: 10.1034/j.1399-3054.2002.1160415.x

Joshi, P. N., Biswal, B., Kulandaivelu, G., and Biswal, U. C. (1994). Response of senescing wheat leaves to ultraviolet A light: changes in energy transfer efficiency and PS II photochemistry. Radiat. Environ. Biophys. 33, 167-176. doi: 10.1007/BF01219339

Kataria, S., Guruprasad, K. N., Ahuja, S., and Singh, B. (2013). Enhancement of growth, photosynthetic performance and yield by exclusion of ambient UV components in C3 and C4 plants. J. Photochem. Photobiol. B, Biol. 127, 140152. doi: 10.1016/j.jphotobiol.2013.08.013

Kyaw, M., Yoshizumi, M., Tsuchiya, K., Izawa, Y., Kanematsu, Y., and Tamaki, T. (2004). Atheroprotective effects of antioxidants through inhibition of mitogenactivated protein kinases. Acta Pharmacol. Sin. 258, 977-985.

Lee, J. H., and Oh, M. M. (2015). Short-term low temperature increases phenolic antioxidant levels in kale. Hortic. Environ. Biotechnol 565, 588-596. doi: 10.1007/s13580-015-0056-7

Lee, M. J., Son, J. E., and Oh, M. M. (2014). Growth and phenolic compounds of Lactuca sativa L. grown in a closed-type plant production system with UV-A, -B, or -C lamp. J. Sci. Food Agri. 942, 197-204. doi: 10.1002/jsfa.6227

Lin, L. Z., and Harnly, J. M. (2009). Identification of the phenolic components of collard greens, kale, and Chinese broccoli. J. Agric. Food Chem. 57, 7401-7408. doi: 10.1021/jf901121v

Liu, M., Li, X., Liu, Y., and Cao, B. (2013). Regulation of flavanone 3-hydroxylase gene involved in the flavonoid biosynthesis pathway in response to UV-B radiation and drought stress in the desert plant, Reaumuria soongorica. Plant Physiol. Biochem. 73, 161-167. doi: 10.1016/j.plaphy.2013.09.016

Mantha, S. V., Johnson, G. A., and Day, T. A. (2001). Evidence from action and fluorescence spectra that UV-induced violet-blue-green fluorescence enhances leaf photosynthesis. Photochem. Photobiol. 73, 249-256. doi: 10.1562/0031-8655(2001)0730249EFAAFS2.0.CO2

Maxwell, K., and Johnson, G. N. (2000). Chlorophyll fluorescence-a practical guide. J. Exp. Bot. 51, 659-668. doi: 10.1093/jxb/51.345.659

Middleton, E. M., and Teramura, A. H. (1993). The role of flavonol glycosides and carotenoids in protecting soybean from ultraviolet-B damage. Plant Physiol. 103, 741-752. doi: 10.1104/pp.103.3.741 
Miller, G., Suzuki, N., Ciftci-Yilmaz, S., and Mittler, R. (2010). Reactive oxygen species homeostasis and signaling during drought and salinity stresses. Plant Cell Environ. 33, 453-497. doi: 10.1111/j.1365-3040.2009.02041.x

Miller, N. J., and Rice-Evans, C. A. (1996). Spectrophotometric determination of antioxidant activity. Redox Rep. 2, 161-171. doi: 10.1080/ 13510002.1996.11747044

Mittler, R., Vanderauwera, S., Gollery, M., and Breusegem, F. V. (2004). Reactive oxygen gene network of plants. Trends Plant Sci. 9, 490-498. doi: 10.1016/j. tplants.2004.08.009

Moreira-Rodríguez, M., Nair, V., Benavides, J., Cisneros-Zevallos, L., and Jacobo-Velázquez, D. A. (2017). UVA, UVB light doses and harvesting time differentially tailor glucosinolate and phenolic profiles in broccoli sprouts. Molecules 227, 1065. doi: 10.3390/molecules22071065

Müller-Xing, R., Xing, Q., and Goodrich, J. (2014). Footprints of the sun: memory of UV and light stress in plants. Front. Plant Sci. 5, 474. doi: 10.3389/ fpls.2014.00474

Neugart, S., Zietz, M., Schreiner, M., Rohn, S., Kroh, L. W., and Krumbein, A. (2012). Structurally different flavonol glycosides and hydroxycinnamic acid derivatives respond differently to moderate UV-B radiation exposure. Physiol. Plant. 145, 582-593. doi: 10.1111/j.1399-3054.2012.01567.x

Olsson, L., Veit, M., Weissenböck, G., and Bornman, J. F. (1998). Different flavonoid response to enhanced UV-B radiation in Brassica napus: isolation, identification and quantification of flavonol glycosides. Phytochemistry 49, 1021-1028. doi: 10.1016/S0031-9422(98)00062-4

Parkhill, J. P., Maillet, G., and Cullen, J. J. (2001). Fluorescence based maximal quantum yield for PS II as a diagnostic of nutrient stress. J. Phycol. 37, 517-529. doi: 10.1046/j.1529-8817.2001.037004517.x

Poljsak, B., Šuput, D., and Milisav, I. (2013). Achieving the balance between ROS and antioxidants: when to use the synthetic antioxidants. Oxid. Med. Cell Longev. 2013, 956792. doi: 10.1155/2013/956792

Razem, F. A., and Bernards, M. A. (2003). Reactive oxygen species production in association with suberization: evidence for an NADPH-dependent oxidase. J. Exp. Bot. 54, 935-941. doi: 10.1093/jxb/erg094

Reifenrath, K., and Müller, C. (2007). Species-specific and leaf-age dependent effects of ultraviolet radiation on two Brassicaceae. Phytochemistry 68, 875885. doi: $10.1016 /$ j.phytochem.2006.12.008

Riley, P. A. (1994). Free radicals in biology: oxidative stress and the effects of ionizing radiation. Int. J. Radiat. Biol. 651, 27-33. doi: 10.1080/09553009414550041

Shen, J., Jiang, C., Yan, Y., Liu, B., and Zu, C. (2017). Effect of increased UV-B radiation on carotenoid accumulation and total antioxidant capacity in tobacco (Nicotiana tabacum L.) leaves. Genet. Mol. Res. 16, 1-11. doi: 10.4238/ gmr16018438

Song, S. J., and Hansen, U. (1994). Stress effects on photosynthesis of greenhouse plants as measured by the fluorescence method. Korean J. Environ. Agric. 13, 183-190.

Tattini, M., Galardi, C., Pinelli, P., Massai, R., Remorini, D., and Agati, G. (2004). Differential accumulation of flavonoids and hydroxycinnamates in leaves of
Ligustrum vulgare under excess light and drought stress. New Phytol. 163, 547561. doi: 10.1111/j.1469-8137.2004.01126.x

Tezuka, T., Yamaguchi, F., and Ando, Y. (1994). Physiological activation in radish plants by UV-A radiation. J. Photochem. Photobiol. B, Biol. 24, 33-40. doi: 10.1016/1011-1344(94)07006-7

Torres, A. P., and Lopez, R. G. (2011). Photosynthetic daily light integral during propagation of Tecoma stans influences seedling rooting and growth. HortScience 46, 282-286. doi: 10.21273/HORTSCI.46.2.282

Tsormpatsidis, E., Henbest, R. G. C., Davis, F. J., Battey, N. H., Hadley, P., and Wagstaffe, A. (2008). UV irradiance as a major influence on growth, development and secondary products of commercial importance in Lollo Rosso lettuce 'Revolution' grown under polyethylene films. Environ. Exp. Bot 631, 232-239. doi: 10.1016/j.envexpbot.2007.12.002

Turcsányi, E., and Vass, I. (2000). Inhibition of photosynthetic electron transport by UV-A radiation targets the photosystem II complex. Photochem. Photobiol. 72, 513-520. doi: 10.1562/0031-8655(2000)072<0513:IOPETB > 2.0.CO;2

Verdaguer, D., Jansen, M. A., Llorens, L., Morales, L. O., and Neugart, S. (2017). UV-A radiation effects on higher plants: exploring the known unknown. Plant Sci. 255, 72-81. doi: 10.1016/j.plantsci.2016.11.014

Wang, A. G., and Luo, G. H. (1990). Quantitative relation between the reaction of hydroxylamine and superoxide anion radicals in plants. Plant Physiol. Commun. 655, 57.

Wanner, L. A., Li, G., Ware, D., Somssich, I. E., and Davis, K. R. (1995). The phenylalanine ammonia-lyase gene family in Arabidopsis thaliana. Plant Mol. Biol. 272, 327-338. doi: 10.1007/BF00020187

Yarosh, D. B., and Smiles, K. A. (2009). "DNA repair and photoprotection," in Clinical guide to sunscreens and photoprotection. Eds. H. W. Lim and Z. D. Draelos (New York, NY: Inform Healthcare), 169-197. doi: 10.3109/9781420080858.012

Zhang, L., Allen, L. H., Jr., Vaughan, M. M., Hauser, B. A., and Boote, K. J. (2014). Solar ultraviolet radiation exclusion increases soybean internode lengths and plant height. Agric. Forest Meteorol. 184, 170-178. doi: 10.1016/j. agrformet.2013.09.011

Zhou, B., Li, Y., Xu, Z., Yan, H., Homma, S., and Kawabata, S. (2007). Ultraviolet A-specific induction of anthocyanin biosynthesis in the swollen hypocotyls of turnip (Brassica rapa). J. Exp. Bot. 587, 1771-1781. doi: 10.1093/jxb/erm036

Conflict of Interest Statement: The authors declare that the research was conducted in the absence of any commercial or financial relationships that could be construed as a potential conflict of interest.

Copyright (c) 2019 Lee, Oh and Son. This is an open-access article distributed under the terms of the Creative Commons Attribution License (CC BY). The use, distribution or reproduction in other forums is permitted, provided the original author(s) and the copyright owner(s) are credited and that the original publication in this journal is cited, in accordance with accepted academic practice. No use, distribution or reproduction is permitted which does not comply with these terms. 